dr. Vida A.

Mohorčič

Špolar

Andragoški

center Slovenije

\title{
DEMOKRACIJA 21. STOLETJA SE ZAČENJA V DRUŽINAH
}

\section{Kako priti do demokratičnih odnosov in kje se jih učimo?}

$\mathrm{N}$ v okviru študije Politična socializacija na Nizozemskem, študija dosežkov in razvoja političnih stališč mladostnikov (1995) anketiral 10.000 mladostnikov v starosti od 15 do 17 let in ugotavljal, kakšna so njihova politična stališča in kakšno je njihovo zanimanje za aktivno državljanstvo potem, ko so obiskovali intenzivni tečaj državljanske vzgoje (dve šolski leti štiri ure na teden). Ugotovitve so zanimive. Poročajo, da »verska, družbena in etnična sestava šole ne vpliva na politična stališča učencev « in da je zanimanje učencev za politiko ter politična vprašanja povezano tudi z izobrazbo njihovih staršev. Čim višjo izobrazbo imajo starši, tem večje je zanimanje učencev za tovrstno problematiko. Pokazalo se je tudi, da intenzivnejša vzgoja za aktivno državljanstvo ne pripomore $k$ povečanju tolerance do drugačnih in drugače mislečih. Vendar je eden temeljnih ciljev izobraževanja za aktivno državljanstvo prav ta tolerantnost. Pri takih rezultatih se seveda poraja vprašanje, kje in kdaj začeti s takim izobraževanjem, koliko ur mu nameniti in kdo ima na vsebine izobraževanja za aktivno državljanstvo največji vpliv: izobraževalne institucije ali družina.

Odgovor na vprašanje, kdaj in kje začeti izobraževanje za aktivno državljanstvo, ni lahek. $\mathrm{V}$ vrtcu, v osnovni šoli ali kasneje. Rezultati raziskave, ki jo je opravila dr. Ana Krajnc, o tem, kje je demokratičnost izobraževanja in možnost odločanja največja, bi govorili v korist temu, da se začne v vrtcu in se nadaljuje $\mathrm{v}$ osnovni šoli. Vendar bi moral biti človek, poznavajoč vsebino programa Civics, na primer pri kurikulumu vrtcev in šol v Združenih državah Amerike previden. V ZDA traja izobraževanje za aktivno državljanstvo osem let. Začne se, kot poročajo, v vrtcu in nadaljuje do 12. razreda (v ZDA otroci obiskujejo šolo do 16. leta starosti) obveznega izobraževanja. Bežen pregled vsebine tega izobraževanja pove, da je program izredno indoktriniran.

Odgovor na to, kdo ima največji vpliv na izobraževanje za aktivno državljanstvo v Sloveniji, bo dala raziskava Izobraževanje in usposabljanje za aktivno državljanstvo v Evropi, ki jo bo začel Andragoški center Slovenije v letu 2000 in dokončal do leta 2003. Glede na izsledke nizozemske raziskave bi lahko sklepali, da ima največji vpliv družina oziroma izobrazba staršev. Videli bomo, ali bodo pri nas izsledki raziskave drugačni. $\mathrm{Na}$ podlagi tega bi morali koncipirati tudi programe izobraževanja za aktivno državljanstvo. Tako stanje pa se kljub vsemu ne more izogniti vprašanjem, kot so: kdaj začeti izobraževati, pri kateri starosti, kakšne vsebine in kako. In to se mi zdi eno temeljnih vprašanj, ki bi jih bilo treba rešiti. 